\title{
Occurrence of Diseases of Medicinal and Aromatic Plants in Homestead Garden under Red and Lateritic Zone of West Bengal
}

\author{
Nisha Thakur*, Swagatika Das and Bholanath Mondal \\ Department of Plant Pathology, Palli-Siksha Bhavana (Institute of Agriculture), \\ Visva- Bharati, Sriniketan-731236, West Bengal, India \\ *Corresponding author
}

Keywords

Biotic stress,

Disease, Homestead garden, Medicinal plant

Article Info

Accepted:

14 November 2020

Available Online:

10 December 2020

\section{A B S T R A C T}

\begin{abstract}
Medicinal and Aromatic plants are economically important plants, rich in secondary metabolites, and are potential sources of drugs. The use of medicinal plants has attained an important role in health system all over the world. Various types of pathogenic infections play a major role in lowering the qualitative and quantitative production of medicinal plants. To record the current disease situation of such plants from different homestead gardens of Bolpur-Sriniketan block a study was undertaken during 2018-2019by using standard methods. Detail symptomatology and disease incidence of different medicinal and aromatic plants were recorded. Laboratory investigation like culturing of pathogen and microscopic investigation was made for confirmation of the disease. A number of diseases of such plants were recorded with mild to severe form in homestead garden under the study area. Among the diseases, leaf spot of aloe vera (Alternaria alternata), leafspot of asiatic pennywort (Curvularia sp.), leaf blotch of turmeric (Taphrina maculans), powdery mildew of holi basil (Erysiphe biocellata), anthracnose of periwinkle (Colletotrichum dematium), Alternaria blight of garlic (Alternaria porri) and canker of acid lime(Xanthomonas axonopodis pv. citri) were more common. White rot of Starthorn (Sclerotinia sclerotiorum) was also recorded in homestead garden. No abiotic diseases were observed during the investigation.
\end{abstract}

\section{Introduction}

Medicinal and Aromatic plants are economically important plants, rich in secondary metabolites or compound (include tannins, alkaloids, flavonoids, glycosides, steroids, phenolic compound etc.) and potential source of drugs, which provide basic raw materials for medicines, perfumes, flavours and cosmetics. These plants and their products help nation to earn valuable foreign exchange by way of export and also serve as valuable sources of income for small holders and entrepreneurs. India is a land of biodiversity and rich source of Medicinal and Aromatic plants; among them around $70 \%$ of the plants are spread across tropical forests of Western Ghats, Terai region, North-East Himalayas' regions. Among all the plants more than 20,000 plants are having 
therapeutic activity and they are now as modern medicinal crops from the wild plants by sustainable agricultural development in favourable climate and environmental conditions (Das, 2010). According to Davidson (2000), India has a very rich diversity of plant species in a wide range of ecosystems. He mentioned that among 17,000 species (aprox.) of higher plants 8,000 species (aprox) have considered as medicinal, and utilized by village communities, particularly tribal communities, or in traditional medicinal systems, such as the Ayurveda.

Red and Lateritic zone of West Bengal is one of the major sources of medicinal and aromatic plants (Thakur et al., 2020). Some parts of the Birbhum district are tribal dominated. They used to cure their ailments mainly by collecting different types of herbs grown naturally in jungle, rode side or surrounding their house. Some of the inhabitants have grown medicinal and aromatic plants in their homestead gardens for their own use. They are facing problem to grow such plants for disease pest infestation. Attempts were made to record such valuable information as there is no clear cut picture of disease infestation of medicinal and aromatic plants in homestead gardens.

\section{Materials and Methods}

Surveys were carried out during February, 2018 - March, 2019 to record the disease incidence of medicinal and aromatic plants in Homestead gardens of Bolpur-Sriniketan block. Eighty numbers of households covering 8 different villages (viz. Amdahara, Sahebdanga, Sukhbazar, Damdama, Keodaha, Kuchudanga, Barodanga and Sriniketan) in 4 Gram Panchayats (viz. Kankalitala, Sian Muluk, Albandha Sarpolehona and Ruppur) were under the survey programme.

During survey, the detail symptoms and incidence of different diseases were recorded.
Plants were selected randomly to examine closely for studying the characteristics of symptoms on the hosts. Besides, infected plant parts were brought to the Plant Pathology laboratory for confirmation and further study. Incidence of the diseases was taken following standard disease severity scale, and per cent disease index (PDI) was calculated.

In laboratory, pathogen was cultured in PDA medium. Transverse section of the infected portion was made and examine under microscope for observation of aetiology of the pathogen. Infected plant parts were also kept in submerged condition in aqueous medium for production of mycelium and sporulation (Mondal et al., 2015). Ooze test was performed too for suspected bacterium infected plants and also cultured in NA medium.

\section{Results and Discussion}

During study, numbers of medicinal and aromatic plants found infested with different diseases. Such diseased plants produced characteristics symptoms. The symptoms were recorded time to time. Microscopic observations, growth habits of pathogens in PDA/NA medium or in aqueous medium were recorded. No abiotic diseases were observed during the investigation. Results of the experiment were summarized below:

\section{Leaf spot of Aloe vera (Aloe barbadensis L., Family: Aloaceae)}

\section{Symptoms}

Small circular to oval dark brown necrotic spots on leaves were characterised by grey centres with brown margins. Black sporulation appeared in the centre of the spots. The affected leaves dried from the tip to downwards and lost the mucilaginous jelly (Plate 1). Incidence of the disease was 
moderate to high, and it was $10.22-38.95 \%$ (Table 1).

\section{Laboratory study}

The conidiophores were branched and straight; dark brown coloured obclavate conidia produced in long chains (Plate 1). Average size of the conidia was $14.34 \mu \mathrm{m} \times$ $3.16 \mu \mathrm{m}$.

\section{Causal pathogen}

The study revealed that the pathogen is Alternaria alternata (Fr.) Keissl.

In earlier, Mondal et al., (2012) recorded leaf spot of aloe vera caused by Colletotrichum gloeosporioides from Nadia and Birbhum, whereas, in the present investigation a separate leaf spot disease caused by Alternaria alternata was recorded.

Leaf spot of Thankuni/Asiatic pennywort (Centella asiatica (L.) Urban, Family: Apiaceae)

\section{Symptoms}

Minute circular to semi-circular, light-brown spots appeared on leaves, spots were darkbrown, leaves turned yellow and defoliated prematurely (Plate 2). In some cases, the entire leaf lamina was covered by numerous spots. Incidence of the disease was moderate to high, and it was $6.23-8.13 \%$ (Table 1).

\section{Laboratory study}

Both conidia and hyphae were dark brown. The conidia were 3-4 septate and mostly curved about the third cell from the base. Straight conidia were also seen. The conidiophore forms a sympodula bearing a cluster of conidia (Plate 2). Average size of conidia was $9.57 \mu \mathrm{m} \times 4.27 \mu \mathrm{m}$.

\section{Causal pathogen}

The study revealed that the pathogen is Curvularia sp.

Foot rot of Centella asiatica caused by Sclerotium rolfsii was recorded earlier from Nadia, South 24 Parganas and Birbhum (Mondal et al., 2012), while leaf spot disease was recorded in present investigation.

\section{Alternaria blight of Rosun/garlic (Allium sativum L., Family: Alliaceae)}

\section{Symptoms}

Small white lesions appeared on leaves were enlarged into elliptical purplish areas with yellowish border. Formation of dark and light concentric zones were recorded may be due to sporulation on these lesions (Plate 4). Incidence of the disease was moderate to high, and it was $4.22-6.89 \%$ (Table 1).

\section{Laboratory study}

Conidiophore was straight, septate and pale to mid brown. Conidia formed singly, and were straight or curved, obclavate to elongate-oval, tapering beak and pale to mid-golden brown in colour, having transverse septa and longitudinal septa (Plate 4). Average size measured was $7.50 \mu \mathrm{m} \times 2.12 \mu \mathrm{m}$

\section{Causal pathogen}

The study revealed that the pathogen is Alternaria porri (Ellis) Cif.

Leaf blotch of Haldi/turmeric (Curcuma longa L., Family: Zingiberaceae)

\section{Symptoms}

Disease symptom appeared as small, oval, rectangular or irregular brown spots on either 
side of leaves which soon become dirty yellow or dark brown. The leaves also turned yellow (Plate 7). Incidence of the disease was moderate to high, and it was $8.85-12.67 \%$ (Table 1).

\section{Laboratory study}

The fungus produced abundant mycelium in the leaf tissues. Formation of asci and ascospores without formation of stalk cells were also recorded.

\section{Causal pathogen}

The study revealed that the pathogen is Taphrina maculans E.J. Butler.

Powdery mildew of Tulsi /Holi Basil
(Ocimum tenuiflorum
Lamiaceae)

\section{Symptoms}

White powdery talcum powder like growth appeared on both surfaces of leaves, twigs and stems. Powdery growth was recorded more in upper surface than the lower surface. Infected leaves dried out (Plate 5).Incidence of the disease was moderate to high, and it was $10.22-38.05 \%$ (Table 1).

\section{Laboratory study}

On microscopic observation, rectangular shaped chain of oidia was recorded (Plate 5).

\section{Causal pathogen}

The study revealed that the pathogen is Erysiphe biocellata Ehrenb.

The disease was also recorded earlier from Nadia, South 24 Parganas and Birbhum (Mondal et al., 2012).

\begin{abstract}
Anthracnose of Nayantara/Periwinkle (Catharanthus roseus L., Family: Apocynaceae)
\end{abstract}

\section{Symptoms}

Dark brown to black girdling lesions appeared on the twigs. Darkbrown to blackish water soaked lesions also found on leaves and severely infected leaves were fallen on ground. In some cases, drying of whole twig was recorded. On the infected plant parts numerous minute black dots were recorded. Microscopic observation revealed that these black dots are actually acervuli containing masses of spores and dark setae (Plate $3)$.Incidence of the disease was moderate to high, and it was $10.54-20.50 \%$ (Table 1).

\section{Laboratory study}

On microscopy, numerous acervuli were recorded along with black needle shaped sitae in infected branches (Plate 1). Pathogen also produced abundant acervuli in agar medium. The observation is corroborated with Mondal et al., (2014) who isolated Colletotrichum dematiumin agar medium from infected Catharanthus roseus plant. According to them, the pathogen produced dark brown or almost black septate and smooth setae, which tapered towards tip, and size ranging from $34.5 \mu \mathrm{m}-198.85 \mu \mathrm{m}$ in length. They recorded small and hyaline conidiophores, and hyaline, aseptate, smooth, falcate or fusiform conidia. Size of the conidia varied from $16.15 \mu \mathrm{m}-$ $26.72 \mu \mathrm{m} \times 3.20 \mu \mathrm{m}-5.69 \mu \mathrm{m}$.

\section{Causal pathogen}

The study revealed that the pathogen is Colletotrichum dematium (Pers.) Grove. 
Table.1 Incidence of different diseases of medicinal plants in homestead garden

\begin{tabular}{|l|l|l|l|}
\hline $\begin{array}{l}\text { Name of } \\
\text { crops }\end{array}$ & Disease & Pathogen & $\begin{array}{l}\text { Disease } \\
\text { incidence } \\
(\%)\end{array}$ \\
\hline Starthorn & White rot & Sclerotinia sclerotiorum (Lib.) de Bary & $2.21-8.90$ \\
\hline Garlic & $\begin{array}{l}\text { Alternaria } \\
\text { blight }\end{array}$ & Alternaria porri (Ellis) Cif. & $4.22-6.89$ \\
\hline Aloe vera & Leaf spot & Alternaria alternata (Fr.) Keissl. & $10.22-38.95$ \\
\hline $\begin{array}{l}\text { Asiatic } \\
\text { pennywort }\end{array}$ & Leaf spot & Curvularia sp. & $6.23-8.13$ \\
\hline Periwinkle & Anthracnose & Colletotrichum dematium (Pers.) Grove & $10.54-20.50$ \\
\hline Holi Basil & $\begin{array}{l}\text { Powdery } \\
\text { mildew }\end{array}$ & Erysiphe biocellata Ehrenb. & $10.22-38.05$ \\
\hline Turmeric & Leaf blotch & Taphrina maculans E.J. Butler & $8.85-12.67$ \\
\hline Acid lime & Canker & $\begin{array}{l}\text { Xanthomonas axonopodis pv. citri(Hasse) } \\
\text { Vauterin, Hoste, Kersters \& Swings. }\end{array}$ & $2.45-31.44$ \\
\hline
\end{tabular}

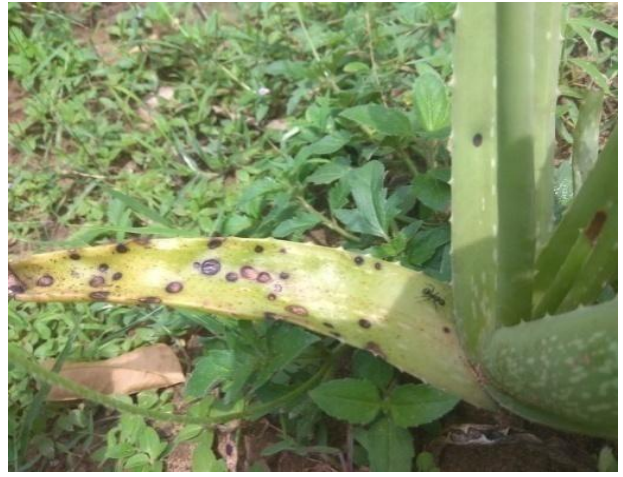

Plate 1. Leaf spot of Aloe vera

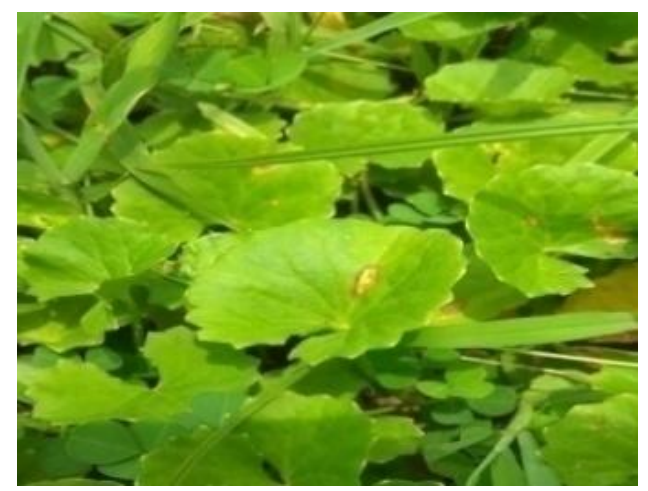

Plate 2. Leaf spot of thankuni

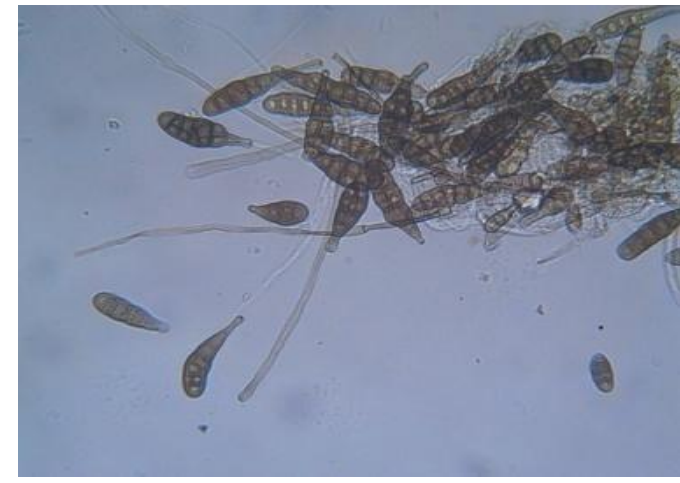

C.O.: Alternaria alternate

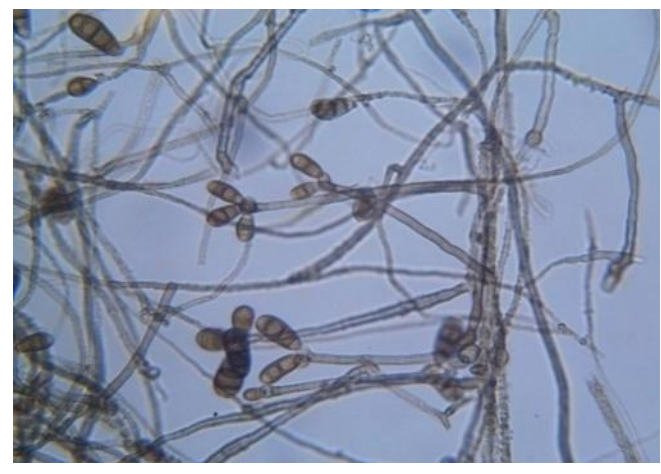

C.O.: Curvularia sp. 


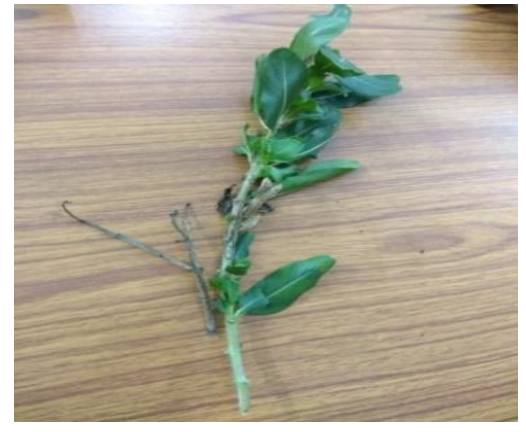

Plate 3. Leaf spot of periwinkle

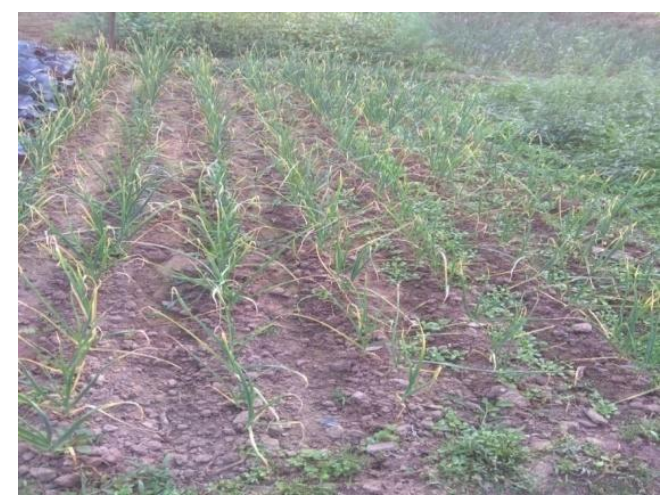

Plate 4. Alternaria blight of garlic

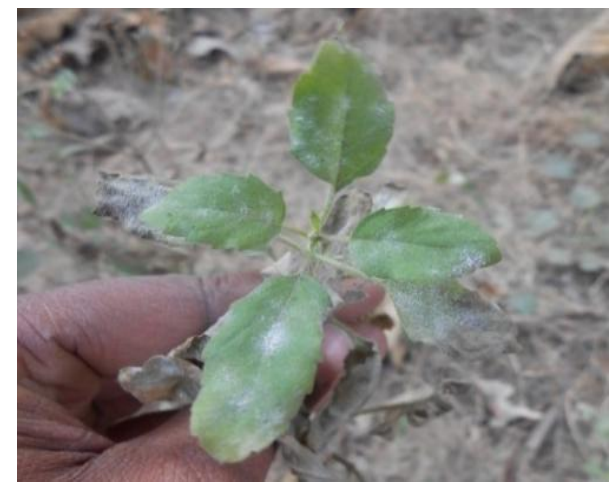

Plate 5. Powdery mildew of holi basil

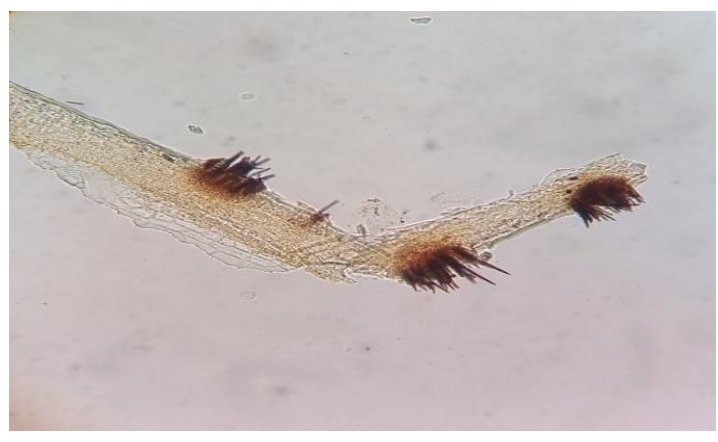

C.O.: Colletotrichum dematium

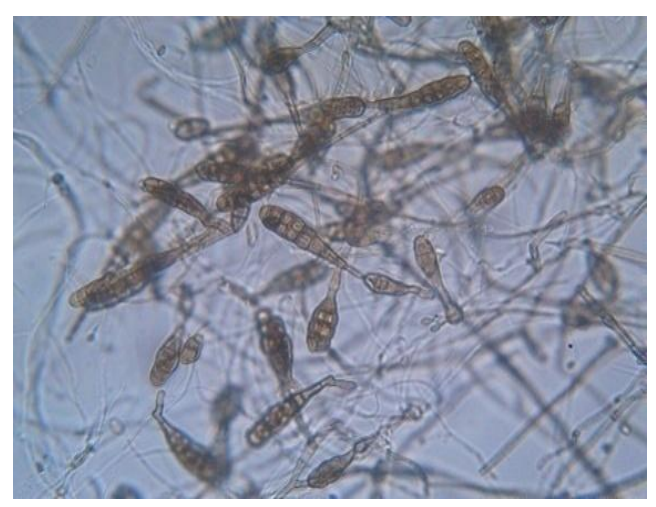

C.O.: Alternaria porri

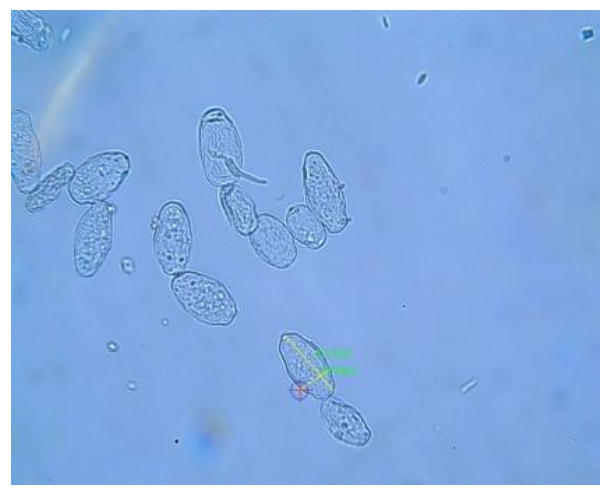

C.O.: Erysiphe biocellata 


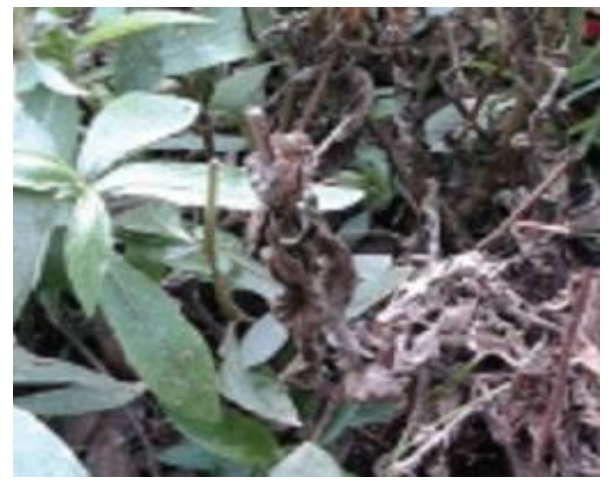

Plate 6. White rot of starthorn

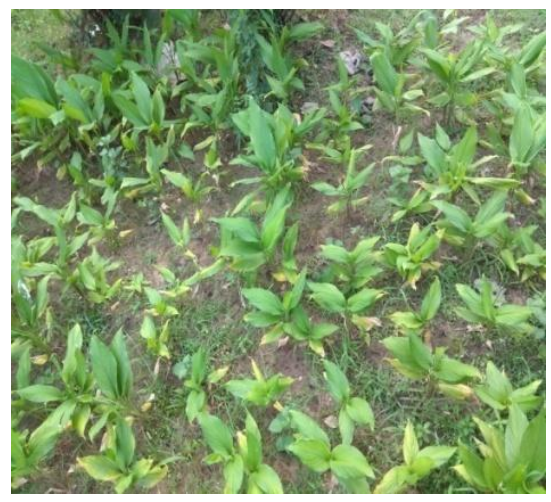

Plate 7. Leaf blotch of turmeric

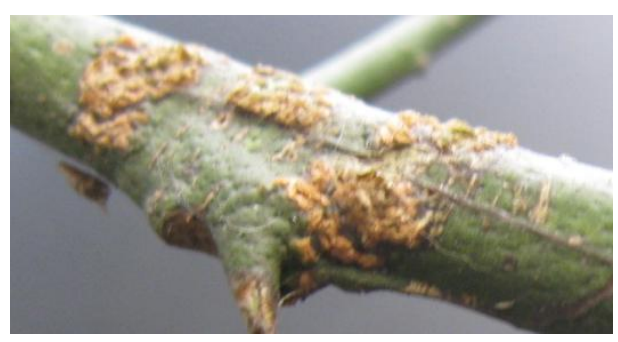

Plate 9. Stem canker of citrus

White rot of Kulekhara/ Starthorn (Hygrophila auriculata (Schum.) Heynne., Family: Acanthaceae)

\section{Symptoms}

Water soaked lesions were produced on branches and leaves. The affected area

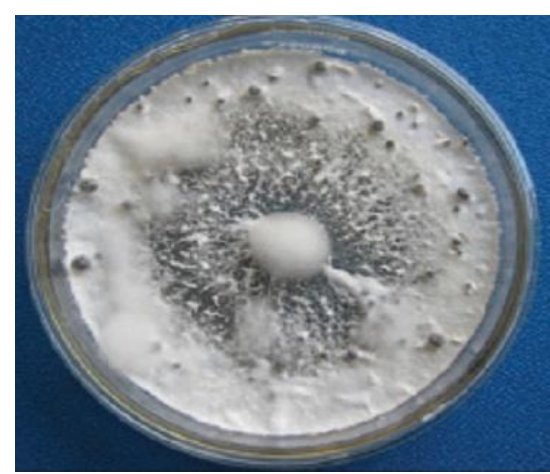

\section{C.O.: Sclerotinia sclerotiorum}

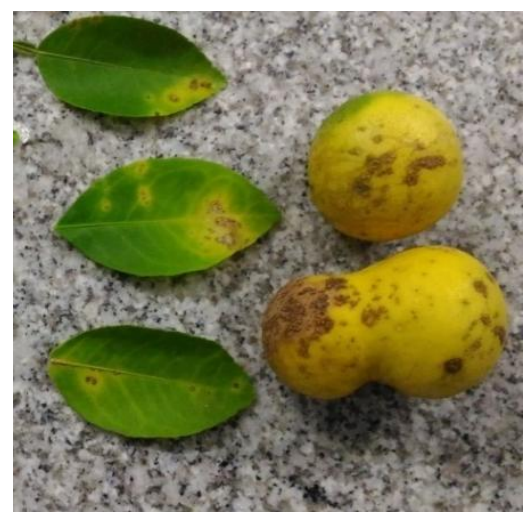

Plate 8. Leaf and fruit canker of citrus

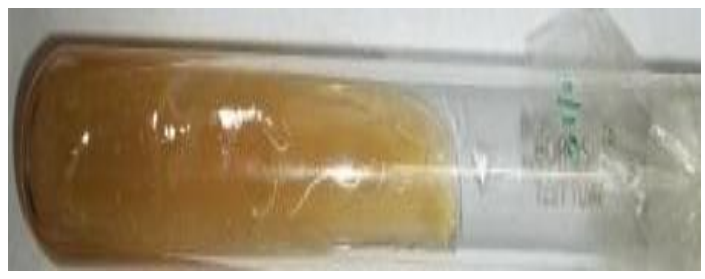

Plate 10. Growth of Xac in NA medium

covered with white mycelial growth of the causal fungus within 2-3 days. Many plants died. Sclerotia formation was not found on the infected plants but more or less spherical large and black sclerotia were produced in soil at base of the infected plant (Plate 6). Incidence of the disease was moderate to high, and it was $2.21-8.90 \%$ (Table 1). 


\section{Laboratory study}

White mycelium with hyaline, branched and septate hyphae was produced by the pathogen on PDA medium. Black sclerotia near spherical in shape generally were formed within 4-6 days of incubation at $25^{\circ} \mathrm{C}$ (Plate $6)$.

\section{Causal pathogen}

The study revealed that the pathogen is Sclerotinia sclerotiorum (Lib.) de Bary.

Sclerotinia rot of Kulekhara was recorded earlier in a homestead gardens at Sriniketan (Birbhum district) of West Bengal during winter months of January-February, 2014 and2015 (Mondal et al., 2016).

\section{Canker of Kagjilebu/acid lime (Citrus aurantifolia (Christm.) Swingle, Family: Rutaceae)}

\section{Symptoms}

Minute, water soaked, rough, raised, round, yellowish spots that were eruptive and corky were recorded on leaves surrounded by a characteristics yellow halo. Similar lesions observed on fruits without yellow hallow. Severe lesions on fruit may coalesced to form larger canker (Plate 8 and 9). Incidence of the disease was moderate to high, and it was 2.45 $-31.44 \%$ (Table 1).

\section{Laboratory study}

Rod shaped, gram negative bacterial cells were observed under microscope (100x objective lens) through gram staining and negative staining. Characteristics bacterial growth was recorded in NA medium (Plate $10)$.

\section{Causal pathogen}

The study revealed that the pathogen is Xanthomonas axonopodis pv. citri (Hasse) Vauterin, Hoste, Kersters \& Swings.

Mondal et al., (2017) studied in details about the incidence of citrus canker on acid lime in red and lateritic agro-climatic zone of West Bengal, India.

In conclusion, significance of biotic stresses of medicinal and aromatic plants has been explored in the present investigation. Various types of pathogenic infection play a major role in lowering down the qualitative and quantitative production of medicinal and aromatic plants in homestead garden. So, ecofriendly plant protection measures should be taken to keep safe their crops from infection of such pathogens. It is necessary to impart training and start awareness build-up programme amongst the homestead gardener in Bolpur-Sriniketan block to make it remunerative.

\section{References}

Das, K., Tiwari, R. K. S. and Shrivastava, D. K. (2010). Techniques for evaluation of medicinal plant products as antimicrobial agent: Current methods and future trends. Journal of Medicinal Plants Research, 4(2): 104-111. DOI: 10.5897/JMPR09.030

Davidson-Hunt, I., (2000). Ecological ethno botany: stumbling toward new practices and paradigms. MASA Journal, 16: 113.

Mondal, B., Debbarma, P. and Khatua, D. C. (2016). Sclerotnia Rot of Hygrophila auriculata (Schum.) Heynne. in Lateritc Zone of West Bengal, India. International Journal of Bio-resource and Stress Management, 7(5):11651167 DOI: 10.5958/0976- 
4038.2016.00195.0

Mondal, B., Hansda, S. and Khatua, D. C. (2014). Incidence of anthracnose of Catharanthus roseus in plains of West Bengal. International Symposium on Role of Fungi and Microbes in the $21^{\text {st }}$ Century - A Global Scenario, held on 20-22 February, 2014, organised by Indian Mycological Society, Kolkata in collaboration with Department of Botany, University of Calcutta, pp. 133.

Mondal, B., Mahapatra, S., Khatua, D.C. (2012). Recordsof some new diseases of horticultural plants of WestBengal. Journal of Interacademicia, 16(1): 3643.

Mondal, B., Pauria, N. K. and Khatua, D. C. (2015). Rapid Laboratory Evaluation of Fungicides against Phytophthora infestans Causing Late Blight of Potato. Journal of Scientific Research \& Reports, 4(2): 168-173. DOI: 10.9734/JSRR/2015/13107

Mondal, U., Mondal, B. and Mondal, P. (2017). Incidence of citrus canker on acid lime in red and lateritic agroclimatic zone of West Bengal, India. International Journal of Bio-Resource, Environment and Agricultural sciences, 3(1): 453-458.

Thakur, N., Das, S., Singh, R. K. and Mondal, B. (2000). Biodiversity of Medicinal Plants in Homestead Garden of BolpurSriniketan Block of West Bengal, India. Scholars Academic Journal of Biosciences, 8(8): 244-248. DOI: 10.36347/sajb.2020.v08i08.003.

\section{How to cite this article:}

Nisha Thakur, Swagatika Das and Bholanath Mondal. 2020. Occurrence of Diseases of Medicinal and Aromatic Plants in Homestead Garden under Red and Lateritic Zone of West Bengal. Int.J.Curr.Microbiol.App.Sci. 9(12): 1809-1817. doi: https://doi.org/10.20546/ijcmas.2020.912.215 